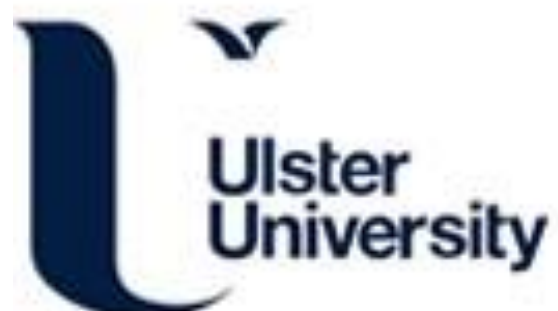

\section{Characterisation of calcium phosphate/titanium dioxide hybrid coatings}

Boyd, A., Burke, GA., Duffy, H., Cairns, ML., O'Hare, P., \& Meenan, BJ. (2008). Characterisation of calcium phosphate/titanium dioxide hybrid coatings. JOURNAL OF MATERIALS SCIENCE-MATERIALS IN MEDICINE, 19(2), 485-498. https://doi.org/10.1007/s10856-006-0031-z

Link to publication record in Ulster University Research Portal

Published in:

JOURNAL OF MATERIALS SCIENCE-MATERIALS IN MEDICINE

Publication Status:

Published (in print/issue): 01/02/2008

DOI:

10.1007/s10856-006-0031-z

Document Version

Publisher's PDF, also known as Version of record

\section{General rights}

Copyright for the publications made accessible via Ulster University's Research Portal is retained by the author(s) and / or other copyright owners and it is a condition of accessing these publications that users recognise and abide by the legal requirements associated with these rights.

\section{Take down policy}

The Research Portal is Ulster University's institutional repository that provides access to Ulster's research outputs. Every effort has been made to ensure that content in the Research Portal does not infringe any person's rights, or applicable UK laws. If you discover content in the Research Portal that you believe breaches copyright or violates any law, please contact pure-support@ulster.ac.uk. 


\title{
Characterisation of calcium phosphate/titanium dioxide hybrid coatings
}

\author{
A. R. Boyd · G. A. Burke · H. Duffy $\cdot$ M. L. Cairns • \\ P. O'Hare · B. J. Meenan
}

Received: 7 July 2006/ Accepted: 19 October 2006/Published online: 3 July 2007

(C) Springer Science+Business Media, LLC 2007

\begin{abstract}
The role of titanium dioxide $\left(\mathrm{TiO}_{2}\right)$ as a means to engender enhanced stability into calcium phosphate (Ca-P) coatings has been well recognised. Several different methods have been used to create such $\mathrm{Ca}-\mathrm{P} / \mathrm{TiO}_{2}$ hybrid layers on a range of substrates. This paper reports the properties of a $\mathrm{Ca}-\mathrm{P} / \mathrm{TiO}_{2}$ system created by the sputter deposition of hydroxyapatite onto a titanium surface and the subsequent thermal diffusion of $\mathrm{TiO}_{2}$ through the porous $\mathrm{Ca}-\mathrm{P}$ layer. The role of temperature in determining the surface contribution from $\mathrm{TiO}_{2}$ has been determined. Coatings annealed up to $600{ }^{\circ} \mathrm{C}$ did not exhibit any hybrid nature in the uppermost surface, however the coatings annealed to $700{ }^{\circ} \mathrm{C}$ did show the presence of both HA and rutile $\mathrm{TiO}_{2}$. The surfaces annealed to $800{ }^{\circ} \mathrm{C}$ were predominantly rutile $\mathrm{TiO}_{2}$. It was also observed that the $\mathrm{Ca} / \mathrm{P}$ ratio decreased with increasing annealing temperature and that the coating annealed to $700{ }^{\circ} \mathrm{C}$ had a value of $1.82 \pm 0.07$, which was closest to stoichiometric HA. Furthermore, the coatings that were annealed to $700{ }^{\circ} \mathrm{C}$ displayed a $\mathrm{Ca}-\mathrm{P} / \mathrm{TiO}_{2}$ hybrid nature, specifically in their uppermost surface and supported the growth and proliferation of osteoblast-like cells more readily when compared to the HA coatings or the rutile $\mathrm{TiO}_{2}$ surfaces.
\end{abstract}

A. R. Boyd $(\bowtie) \cdot$ G. A. Burke · H. Duffy ·

M. L. Cairns · P. O'Hare · B. J. Meenan

Northern Ireland Bioengineering Centre (NIBEC)/

Nanotechnology and Advanced Materials Research Institute

(NAMRI), University of Ulster at Jordanstown, Shore Road,

Room 25A18, Newtownabbey, Co. Antrim BT37 0QB,

Northern Ireland, UK

e-mail: ar.boyd@ulster.ac.uk

\section{Introduction}

The manipulation of a biomaterial's surface properties is an important element for the provision of key biological processes at the implant-tissue interface $[1,2]$. Calcium phosphate (Ca-P) bioceramics and in particular Hydroxyapatite $\left[\mathrm{HA}-\left(\mathrm{Ca}_{10}\left(\mathrm{PO}_{4}\right)_{6}(\mathrm{OH}) 2\right)\right]$ are a proven class of bioactive materials that have found considerable utility as coatings for orthopaedic and dental implants due to their osteoconductive properties [3]. Their application as thin film coatings onto existing bioinert materials, such as titanium, titanium alloy and stainless steel has received considerable attention, not only to provide the underlying material with enhanced biological functionality, but also to act as a protective layer to prevent the leaching of undesirable metal ions into the surrounding environment [4].

Radio frequency (RF) magnetron sputtering has been shown to produce thin films with the appropriate characteristics for the study of cell surface interactions of the type pertinent in hard tissue replacements [5-7]. However, the stability and performance of as-deposited Ca-P coatings can limit their application, in vivo [8]. In particular, the functionality of such coatings has been shown to be significantly influenced by the dissolution rate, which is a direct consequence of the crystallinity of the coating [9]. Previous studies on the dissolution behaviour of Ca-P coatings have shown that highly crystalline Ca-P coatings are less likely to dissolve than amorphous layers [10-13]. It is desirable that the dissolution rate of these Ca-P surfaces is carefully controlled by providing an adequate degree of crystallinity and thereby maintaining the coating's integrity and subsequent biofunctionality. Various approaches have been developed in order to address these requirements. One recent development has been the addition of titanium dioxide $\left(\mathrm{TiO}_{2}\right)$ into Ca-P coatings using sol-gel or plasma 
spraying techniques so as to create either functionally gradient or hybrid surfaces that have the ability to engender the appropriate interfacial properties [14-18]. Similar studies have been adopted for RF magnetron sputter deposited titanium (Ti) and Ca-P interlayers [4, 19], multilayers [20] and Ti/Ca-P composite coatings [21, 22] with the aim of achieving similar enhancements of the surface properties.

For this study $\mathrm{Ca}-\mathrm{P} / \mathrm{TiO}_{2}$ hybrid coatings have been prepared by a novel thermal diffusion method which uses RF magnetron sputtering to deposit a Ca-P coating to onto a pure polycrystalline titanium surface followed by high temperature processing. The nature of the resultant surfaces has been determined using Fourier Transform Infrared Spectroscopy (FTIR), X-Ray Diffraction (XRD), X-Ray Photoelectron Spectroscopy (XPS) and Scanning Electron Microscopy (SEM). The surfaces were also subjected to in vitro testing using MG63 oseteoblast cells. The purpose of this study was to combine the advantages of thin film coatings and functionally gradient surfaces to produce an interfacial layer that has the potential to add significant value to the surface conditions where the manipulation and control of the cellular response is critical.

\section{Materials and methods}

\section{Sputtering procedure}

Titanium layers were sputter deposited onto abraded Ti$6 \mathrm{Al}-4 \mathrm{~V}$ substrates (Titanium International Ltd.) $(20 \mathrm{~mm} \times 20 \mathrm{~mm} \times 0.5 \mathrm{~mm})$ from two titanium metal targets $((99.995 \%)$ Kurt J. Lesker Ltd, USA) of $76 \mathrm{~mm}$ diameter and $3.2 \mathrm{~mm}$ thickness. The targets were mounted at $45^{\circ}$ to the substrate surface. The break-in procedure prior to deposition was conducted at a ramp rate of $15 \mathrm{~W}$ per min (all with the source shutter closed). The base pressure was below $7 \times 10^{-5}$ Pascals (Pa) with an argon gas flow rate (BOC, 99.995\%) of between 15-20 Sccm at a chamber pressure of $2.0 \mathrm{~Pa}$ and a throw distance of $100 \mathrm{~mm}$. The deposition was performed at $200 \mathrm{~W}$ for $1 \mathrm{~h}$ under the same atmospheric conditions as were used for the target break-in procedure. The approximate power density for the titanium targets was $8.7 \mathrm{~W} \mathrm{~cm}^{-2}$.

HA targets, $76 \mathrm{~mm}$ in diameter and $5 \mathrm{~mm}$ thick were produced by dry pressing HA powder (Merck KGaA, Darmstadt, Germany) at a load of $40 \mathrm{kN}$ for 10 min with a loading rate of $10 \mathrm{kN}$ per min. RF magnetron sputtering was performed using a cluster of three high vacuum Torus $3 \mathrm{M}$ sputtering sources in a custom designed system (Kurt J. Lesker Ltd, USA) each operating with a $13.56 \mathrm{MHz}$ RF generator and an impedance matching network (Huettinger, $\mathrm{GmbH}$, Germany). The sources were all mounted at $45^{\circ}$ to the substrate surface. For deposition from the HA targets the RF power in the sputtering system was ramped up slowly to provide an initial break-in phase, thereby minimizing any thermal shock effects. The break-in prior to deposition from the HA target was conducted at a ramp rate of 5 Watts $(\mathrm{W})$ per min (all with the source shutter closed). The base pressure was below $7 \times 10^{-5} \mathrm{~Pa}$, with an argon gas flow rate (BOC, 99.995\%) of between 15-18 standard cubic centimeters per minute $(\mathrm{Sccm})$ at a chamber pressure of 2.0 Pascals (Pa) and a throw distance of $100 \mathrm{~mm}$. The fragility of the HA targets limited their power absorption capacity and consequently deposition was performed at $150 \mathrm{~W}$ for $5 \mathrm{~h}$ under the same atmospheric conditions as were used for the target break-in procedure. The power density for these HA targets was approximately $3.3 \mathrm{~W} \mathrm{~cm}^{-2}$.

A range of different titanium, Ca-P and $\mathrm{Ca}-\mathrm{P} / \mathrm{TiO}_{2}$ coatings were then produced, as described in Table 1. All samples that were thermally processed were annealed in air at atmospheric pressure and were subjected to a ramp rate of $5{ }^{\circ} \mathrm{C}$ per min to the processing temperature (from room temperature), with a soak time of $2 \mathrm{~h}$ and a ramp rate of $5{ }^{\circ} \mathrm{C}$ per min back down to room temperature.

Characterisation of the HA precursor powder and the $\mathrm{Ca}-\mathrm{P} / \mathrm{TiO}_{2}$ coatings

Fourier Transform Infrared (FTIR) spectroscopy of the samples were carried out using a BIORAD FTS 3000MX Excalibur series instrument with a PIKE Diffuse Reflectance Infrared Fourier Transform Spectroscopy (DRIFTS) accessory. Samples were analysed from $4,000-400 \mathrm{~cm}^{-1}$ in absorbance mode at a resolution of $4 \mathrm{~cm}^{-1}$ with 20 scans per sample.

X-Ray Diffraction (XRD) of the samples were carried using a Bruker D8 Discover Diffractometer fitted with a Gobel Mirror. A CuK $\alpha$ X-ray radiation $(\lambda=0.154 \mathrm{~nm})$ source was employed with diffraction scans obtained at a tube voltage of $40 \mathrm{kV}$ and a tube current of $40 \mathrm{~mA}$. Each diffraction scan was recorded at $2 \theta$ values from $20-50^{\circ}$ with a step size of $0.04^{\circ}$ and a scan dwell time for each increment of $30 \mathrm{~s}$. For the grazing incidence angle XRD studies of $\mathrm{Ca}-\mathrm{P}$ and $\mathrm{Ca}-\mathrm{P} / \mathrm{TiO}{ }_{2}$ coatings on the Ti-6Al-4V substrates the tube angle was set to $0.75^{\circ}$.

X-Ray Photoelectron Spectroscopy (XPS) of the samples were carried out using a Kratos Axis Ultra DLD spectrometer. Spectra were recorded by employing monochromated $\mathrm{AlK} \alpha \mathrm{X}$-rays $(\mathrm{h} v=1486.6$ electron volts $(\mathrm{eV}))$ operating at $15 \mathrm{kV}$ and $5 \mathrm{~mA}$. The base pressure was $1.33 \times 10^{-7} \mathrm{~Pa}$ and the operating pressure was $6.66 \times 10^{-7}$ Pa. A hybrid lens mode was employed during analysis (electrostatic and magnetic), with an analysis area of approximately $300 \mu \mathrm{m} \times 700 \mu \mathrm{m}$ and a take off angle 
Table 1 List of titanium, $\mathrm{TiO}_{2}$, $\mathrm{Ca}-\mathrm{P}$ and $\mathrm{Ca}-\mathrm{P} / \mathrm{TiO}_{2}$ coatings produced and their thermal processing conditions (N/A-not applicable)

\begin{tabular}{lll}
\hline Sample & Sample description & Processing temperature $\left({ }^{\circ} \mathrm{C}\right)$ \\
\hline 1 & Ti-6Al-4V & N/A \\
2 & Ti-6Al-4V + titanium layer & N/A \\
3 & Ti-6Al-4V + titanium layer & 800 \\
4 & Ti-6Al-4V + Ca-P outer layer & N/A \\
5 & Ti-6Al-4V + Ca-P outer layer & 500 \\
6 & Ti-6Al-4V + titanium layer + Ca-P outer layer & N/A \\
7 & Ti-6Al-4V + titanium layer + Ca-P outer layer & 500 \\
8 & Ti-6Al-4V + titanium layer + Ca-P outer layer & 600 \\
9 & Ti-6Al-4V + titanium layer + Ca-P outer layer & 700 \\
10 & Ti-6Al-4V + titanium layer + Ca-P outer layer & 800 \\
\hline
\end{tabular}

(TOA) of $90^{\circ}$ with respect to the sample surface. Wide energy survey scans (WESS) were obtained over the range 0-01300 eV binding energy (BE) at a pass energy of $160 \mathrm{eV}$. High resolution spectra were recorded for $\mathrm{C} 1 \mathrm{~s}$ (278-295 eV), O1s (525-540 eV), Ca2p (340-362 eV), Ti2p (450-470 eV) and P2p (125-140 eV) at a pass energy of $20 \mathrm{eV}$. The Kratos charge neutraliser system was used on all samples with a filament current of $1.8 \mathrm{~A}$ and a charge balance of $3.6 \mathrm{~V}$. Sample charging effects on the measured BE positions were corrected by setting the lowest $\mathrm{BE}$ component of the $\mathrm{C} 1 \mathrm{~s}$ spectral envelope to $285.0 \mathrm{eV}$, i.e. the value generally accepted for adventitious carbon surface contamination [23]. Photoelectron spectra were further processed by subtracting a linear background and using the peak area for the most intense spectral line of each of the detected elemental species to determine the $\%$ atomic concentration.

The surface morphology of the $\mathrm{Ca}-\mathrm{P}$ and $\mathrm{Ca}-\mathrm{P} / \mathrm{TiO}_{2}$ coatings on the Ti-6Al-4V substrates were evaluated using a Hitachi S-3200N variable pressure instrument. All SEM images were obtained in secondary electron (SE) mode using an acceleration voltage of $5 \mathrm{kV}$ and a working distance of 8-10 $\mathrm{mm}$ at focus. The SEM data were collected at a magnification of $3000 \times$ and are presented as grey scale images.

The coating thickness of the titanium layers and the Ca-P coatings were determined using a Dektak 8 stylus profilometer (Veeco Instruments Inc, USA). Measurements were taken across 10 step height positions on each sample created by masking the Ti-6Al-4V substrates with aluminium foil prior to deposition in the sputtering system. A $12.5 \mu \mathrm{m}$ diameter diamond tipped stylus was employed with scans lengths of $1,000 \mu \mathrm{m}$ at a force of $15 \mathrm{mg}$.

\section{Cell culture}

The MG-63 cells derived from an osteosarcoma of a 14year-old male (American Type Culture Collection, Rockville, MD, USA) were used in this study. Cells were cultured in Minimum Essential Medium (MEM) supplemented with $10 \%$ fetal calf serum and antibiotic/antimy- cotic (penicillin $\mathrm{G}$ sodium $100 \mathrm{U} / \mathrm{ml}$, streptomycin $100 \mu \mathrm{g}$ / $\mathrm{ml}$, amphotericin B $0.25 \mu \mathrm{g} / \mathrm{ml}$, (PAA Laboratories $\mathrm{GmbH}$, Austria). Cells were maintained in a humidified atmosphere with $5 \% \mathrm{CO}_{2}$ at $37{ }^{\circ} \mathrm{C}$ and were sub-cultured several times when they reached confluence using $0.25 \%$ trypsin in $\mathrm{Mg}^{2+}$ and $\mathrm{Ca}^{2+}$ free phosphate buffered saline (PBS) before experimental use.

Cell attachment, spreading, and morphology

Cell tracker green CMFDA (5-chloromethylfluorescein diacetate, Molecular Probes Ltd. (UK)) is a fluorescent probe that can be used for the tracing of living cells. The probe has a long cellular retention time and can remain fluorescent after at least $72 \mathrm{~h}$ and four cell divisions. It demonstrates relatively uniform cytoplasmic staining and is photostable during microscopic examination. The probe can therefore be used as a tool to investigate cell viability, cytotoxicity, and cell morphology [24]. For the attachment studies adherent MG-63 cells were labelled prior to seeding on sample surfaces. A $5 \mu \mathrm{M}$ CMFDA solution, prepared in serum free media was added to confluent MG-63 cell monolayer and incubated at $37{ }^{\circ} \mathrm{C}$ for $45 \mathrm{~min}$. The working solution was then replaced with pre-warmed fresh culture medium and the cells were incubated again for a further $30 \mathrm{~min}$. Cells were then trypsinised ( $0.25 \%$ trypsin/EDTA), seeded on the sample surfaces at a density of $10^{5}$ cells $\mathrm{cm}^{-2}$ and allowed to attach for $1 \mathrm{~h}$ under normal culture conditions. Cells were then washed twice in ice cold PBS and fixed in fresh $4 \%$ paraformaldehyde (PFA) at $4{ }^{\circ} \mathrm{C}$ for $20 \mathrm{~min}$ and mounted with aqueous mounting medium containing $1.5 \mu \mathrm{g} / \mathrm{ml}$ propidium iodide (PI) (Vectashield, Vector Laboratories, UK). Fixed samples were then imaged using a Nikon Eclipse 80i fluorescence microscope.

MTT cell proliferation assay

Cell proliferation and viability is a fundamental measurement of cell response to external factors and can be assayed 
using the reduction of 3-(4, 5-dimethylthiazolyl-2)-2, 5diphenyltetrazolium bromide (MTT, Sigma Aldrich, UK). The yellow tetrazolium substrate is reduced enzymatically by mitochondrial dehydrogenases of living cells to yield an intracellular purple formazan product, which can be solubilised and measured spectrophotometrically. The amount of formazan produced is directly proportional to the number of viable cells. The MG63 cells were seeded onto the various surfaces at density of $5 \times 10^{4}$ cells $/ \mathrm{cm}^{-2}$. After $24 \mathrm{~h}$ and $72 \mathrm{~h}$ incubation periods, MTT test solution (final working concentration $0.5 \mathrm{mg} / \mathrm{ml}$ in phenol-free DMEM) was added to the wells in an amount equivalent to $10 \%$ of the cell culture medium. The plates were then incubated for $4 \mathrm{~h}$ at $37{ }^{\circ} \mathrm{C}, 5 \% \mathrm{CO}_{2}$, after which the media was aspirated and the intracellular formazan product was solubilised with acidified isopropanol. After complete dissolution of the formazan crystals the optical density (OD) was measured on an ELISA plate reader (TECAN Sunrise, TECAN Austria) at a test wavelength of $570 \mathrm{~nm}$ and a reference wavelength of $650 \mathrm{~nm}$. All MTT assays were performed in triplicate and repeated three times to confirm that the OD was proportional to the number of cells.

\section{Statistical analysis}

Data for the MTT assay are presented at each time point (24 and $72 \mathrm{~h}$ ) corresponding to the mean \pm standard deviation (SD) of three independent analyses repeated three times. Statistical comparisons of the results were made using one-way analysis of variance (ANOVA). Significant differences $(p<0.05)$ between the means of the control and test groups were analysed by Dunnett's test post-hoc.

The cell culture assays, namely Cell Tracker Green and MTT were performed on the following samples only: the abraded Ti-6Al-4V substrate (control), The titanium layer annealed to $800{ }^{\circ} \mathrm{C}$, the $\mathrm{Ca}-\mathrm{P}$ coating deposited onto the abraded Ti-6Al-4V substrate and annealed to $500{ }^{\circ} \mathrm{C}$ and the Ca-P coatings deposited onto the titanium layers and annealed to $500{ }^{\circ} \mathrm{C}, 700{ }^{\circ} \mathrm{C}$ and $800{ }^{\circ} \mathrm{C}$. This was due to the fact that these surfaces presented the most significant differences in terms of their surface properties as determined using the analytical techniques employed during this study.

\section{Results}

Characterisation of the HA precursor powder

The properties of the HA precursor powder were characterised by FTIR, XRD and XPS to determine the nature of the material prior to its use as a target for the sputter deposition of Ca-P coatings. The FTIR and XRD results for the HA precursor powder have been described previously [13].

The XPS wide energy survey-scan (not shown here) recorded as B.E. [0-1200 eV] versus intensity in counts for the HA precursor powder had peaks corresponding to $\mathrm{Ca} 2 \mathrm{p}_{3 / 2}(347.3 \mathrm{eV}), \mathrm{P} 2 \mathrm{p}(133.3 \mathrm{eV})$ and $\mathrm{O} 1 \mathrm{~s}(531.2 \mathrm{eV})$, which are compatible to those reported in the literature for HA [25-27]. No other elemental species were detected, at least at the detection limits of the instrument $(\sim 0.1$ atomic\% concentration). The presence of carbon $(\mathrm{C} 1 \mathrm{~s})$ in the survey scan at 285.0 is due to the presence of adventitious carbon contamination in the sample [23]. The $\mathrm{Ca} / \mathrm{P}$ ratio of the HA powder, as determined by XPS was $1.63 \pm 0.02$, the value slightly lower than expected for stoichiometric HA (1.67) [28]. However, it should also be noted that XPS is a surface analytical technique and does not analyse the bulk of the material. From these FTIR, XRD and XPS results it is clear that the target precursor powder is a semi-crystalline, carbonated HA.

Characterisation of the Ti-6Al-4V substrate and the $\mathrm{Ca}-\mathrm{P} / \mathrm{TiO}_{2}$ coatings

The Ti-6Al-4V substrate, the titanium layer sputter deposited onto the Ti-6Al-4V substrate, the Ca-P coatings and the $\mathrm{Ca}-\mathrm{P} / \mathrm{TiO}_{2}$ coatings were analysed using FTIR, XRD, XPS, stylus profilometry and SEM to assess the surface properties, both before and after thermal annealing between $500{ }^{\circ} \mathrm{C}$ and $800{ }^{\circ} \mathrm{C}$.

Stylus profilometry

The coating thickness of the titanium layers on the Ti-6Al$4 \mathrm{~V}$ substrates, as determined by stylus profilometry was $533 \pm 43 \mathrm{~nm}$. The coating thickness of the Ca-P coatings was $320 \pm 34 \mathrm{~nm}$.

FTIR of the $\mathrm{Ca}-\mathrm{P} / \mathrm{TiO}_{2}$ coatings

The FTIR results for the as-deposited and $500{ }^{\circ} \mathrm{C}$ annealed Ca-P coatings on the Ti-6Al-4V substrates have been described previously [13]. A typical FTIR spectrum for a Ca-P coating deposited onto the titanium layer prior to annealing is shown in Fig. 1a and clearly illustrates spectral modes associated with $\mathrm{P}-\mathrm{O}$ stretching vibrations between 1,200-900 $\mathrm{cm}^{-1}$ and bands associated with $\mathrm{O}-\mathrm{P}-$ O bending vibrations between $650-400 \mathrm{~cm}^{-1}[23,29,30]$. However, the coatings appear to lack the $\mathrm{O}-\mathrm{H}$ vibrational modes expected for $\mathrm{HA}$ at 3,570 and $630 \mathrm{~cm}^{-1}[23,29,30]$. The bands observed in the range $3,700-3,000 \mathrm{~cm}^{-1}$ and at $1,640 \mathrm{~cm}^{-1}$ can be attributed to traces of adsorbed water in 
the sample [30]. After annealing the same coatings to $500{ }^{\circ} \mathrm{C}$, spectra that were more indicative of the HA target powder were observed, as shown in Fig. 1b. P-O stretching vibrations were observed at 1120,1078, 1020 and $960 \mathrm{~cm}^{-}$ ${ }^{1}$. O-P-O bending vibrations are also present at 578 and $609 \mathrm{~cm}^{-1}$, along with a weak shoulder at $557 \mathrm{~cm}^{-1}$. Furthermore, the presence of $\mathrm{O}-\mathrm{H}$ stretching and librational bands is confirmed at 3,568 and $630 \mathrm{~cm}^{-1}$, respectively. Carbonate $\left(\mathrm{CO}_{3}^{2-}\right)$ was also detected as weak bands between $1,600-1,400 \mathrm{~cm}^{-1}$ and at $879 \mathrm{~cm}^{-1}$, suggesting that carbonate may have substituted for either $\mathrm{OH}^{-}$or $\mathrm{PO}_{4}^{3-}$ positions in the hexagonal lattice [29]. The FTIR spectrum for the Ca-P coating deposited onto the titanium layer and annealed to $600{ }^{\circ} \mathrm{C}$ showed significant differences to the same coating annealed to $500{ }^{\circ} \mathrm{C}$. This spectrum, as illustrated in Fig. 1c still shows the presence of all the expected $\mathrm{PO}_{4}^{3-}$ and $\mathrm{OH}^{-}$vibrational bands expected for HA, however, two broad peaks, which are indicative of $\mathrm{TiO}_{2}$ are clearly observed at approximately $500 \mathrm{~cm}^{-1}$ and $800 \mathrm{~cm}^{-1}$ $[31,32]$. After annealing the same coating to $700{ }^{\circ} \mathrm{C}$, the FTIR data (Fig. 1d) showed a decrease in the intensity of the $\mathrm{O}-\mathrm{H}$ vibrational bands, which were normally observed at $3,570 \mathrm{~cm}^{-1}$ and $630 \mathrm{~cm}^{-1}$. The relative intensity of the $\mathrm{O}-\mathrm{P}-\mathrm{O}$ bending vibration, normally observed at $1120 \mathrm{~cm}^{-1}$ is also seen to decrease significantly in relation to the peak intensities of the other $\mathrm{PO}_{4}^{3-}$ moieties. Furthermore, the relative intensities of the peaks attributed to $\mathrm{TiO}_{2}$ vibrations $\left(500 \mathrm{~cm}^{-1}\right.$ and $\left.800 \mathrm{~cm}^{-1}\right)$ were seen to increase in relation to the same $\mathrm{PO}_{4}^{3-}$ vibrational bands as shown in Fig. 1d. Similar results were observed after annealing the same coating to $800{ }^{\circ} \mathrm{C}$ (not shown here).

\section{XRD of the $\mathrm{Ca}-\mathrm{P} / \mathrm{TiO}_{2}$ coatings}

The XRD pattern for the Ti-6Al-4V substrate (not shown here) after abrasion displayed three intense peaks at $35.9^{\circ}$, $38.9^{\circ}$ and $40.8^{\circ} 2 \theta$, and relate to the 100,002 and 101 reflections, respectively. These are consistent with those observed for the 25, 30 and $100 \%$ intensity peaks in for the International Centre for Diffraction Data (ICDD) file \#441294 for titanium. By comparison, the titanium layer deposited onto the Ti-6Al-4V abraded substrate showed diffraction peaks in similar $2 \theta$ positions, however, the titanium layer exhibits a clear 002 preferred orientation due
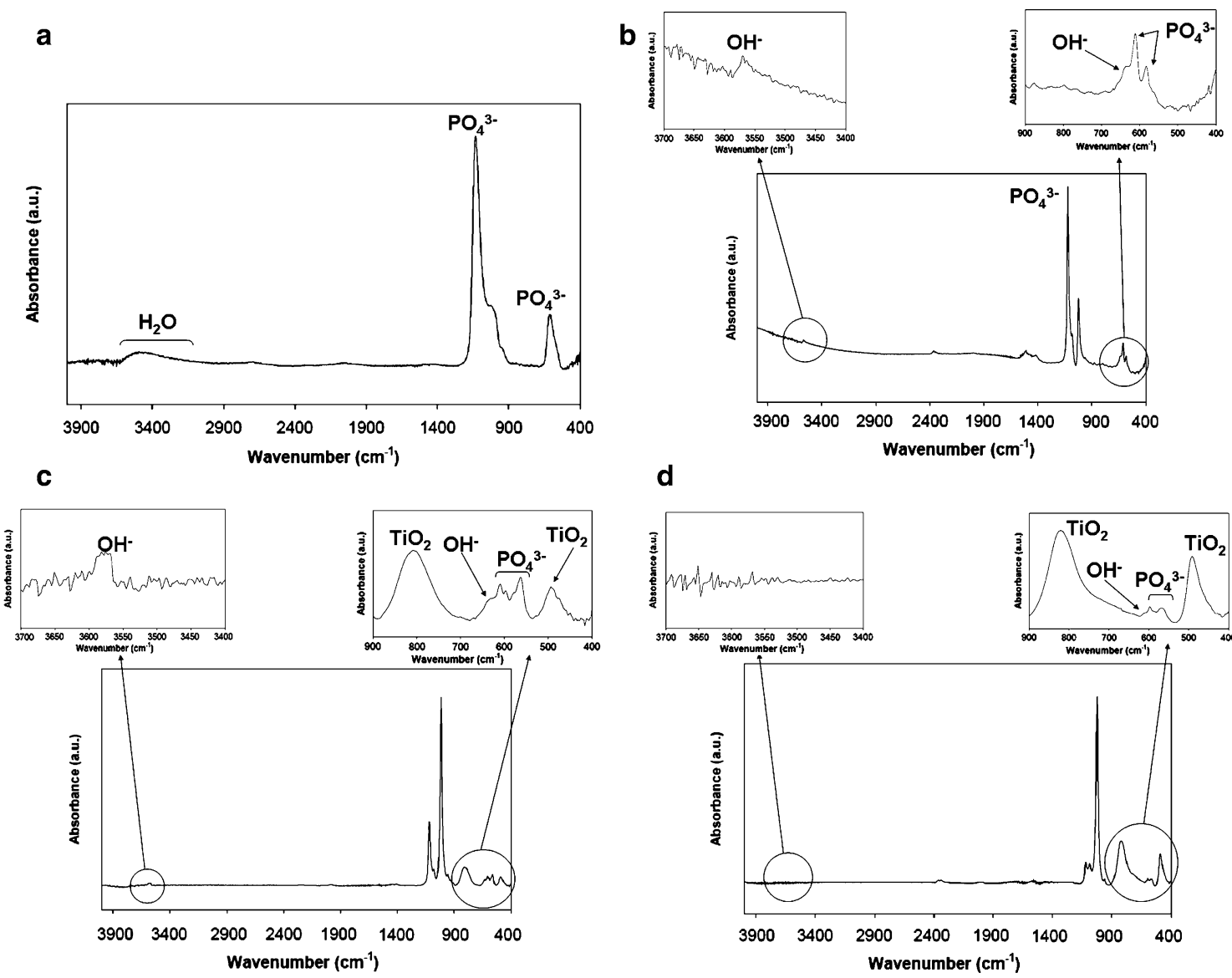

d

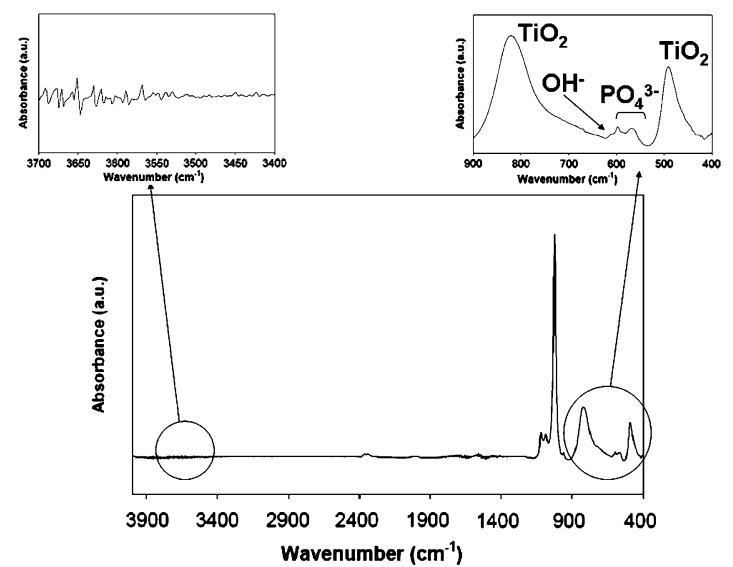

Fig. 1 FTIR spectra for (a) as-received Ca-P coating on titanium layer, (b) Ca-P coating on a titanium layer annealed to $500{ }^{\circ} \mathrm{C}$, (c) $\mathrm{Ca}-\mathrm{P}$ coating on a titanium layer annealed to $600{ }^{\circ} \mathrm{C}$ and (d) Ca-P coating on a titanium layer annealed to $700{ }^{\circ} \mathrm{C}$ 
the peak at $38.9^{\circ} 2 \theta$ dominating the diffraction pattern (not shown here). After annealing this layer to $800{ }^{\circ} \mathrm{C}$, the diffraction pattern (not shown here) exhibits strong peaks at $27.4^{\circ}, 36.1^{\circ}, 39.2^{\circ}, 41.2^{\circ}$ and $44.0^{\circ} 2 \theta$, and these relate to $110,101,200,111$ and 210 reflections, respectively. These peaks are consistent with those observed in the ICDD file \#21-1276 for the rutile phase of $\mathrm{TiO}_{2}$.

The XRD results for the as-deposited and $500{ }^{\circ} \mathrm{C}$ annealed Ca-P coating on the Ti-6Al-4V substrates have been described previously [13]. The XRD pattern for the asdeposited Ca-P coating on the titanium layer, as shown in Fig. 2a exhibits a significant amorphous background hump. Normally, the most intense bands for HA are observed in the $30-35^{\circ} 2 \theta$ range [5]. However, upon heating the Ca-P coating on the titanium layer to $500{ }^{\circ} \mathrm{C}$, as shown in Fig. 2b, a very different diffraction pattern was observed. Peaks that are clearly indicative of HA were seen throughout the pattern with $2 \theta$ values that correspond closely to those observed in the ICDD file \#09-0432 for HA. The four strongest peaks are observed at 25.9, 29.3, 32.1 and $32.3^{\circ} 2 \theta$, and correspond to 002, 210, 211 and 112 reflections, respectively. Furthermore, the 002 reflection at $25.94^{\circ} 2 \theta$ dominates the diffraction pattern, which suggests that this coating may have a 002 preferred orientation [ 31 , 32]. The presence of an amorphous background hump may also indicate the presence of an amorphous Ca-P material in the coating as well. No other Ca-P phases were detected in the XRD patterns for the as-deposited and $500{ }^{\circ} \mathrm{C}$ annealed Ca-P coating on the titanium layers or the Ti-6Al$4 \mathrm{~V}$ substrates. For the Ca-P coating on the titanium layer and heated to $600{ }^{\circ} \mathrm{C}$, significant differences are observed when compared to the same coating heated to $500{ }^{\circ} \mathrm{C}$.

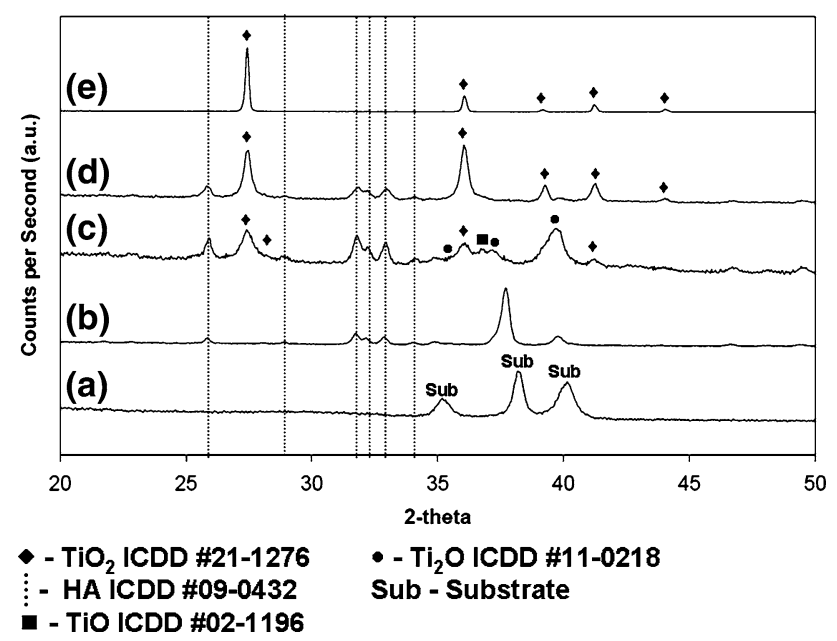

Fig. 2 XRD patterns for (a) Ti-6Al-4V substrate (abraded), (b) Ca-P coating on a titanium layer annealed to $500{ }^{\circ} \mathrm{C}$, (c) Ca-P coating on a titanium layer annealed to $600{ }^{\circ} \mathrm{C}$ (d) $\mathrm{Ca}-\mathrm{P}$ coating on a titanium layer annealed to $700{ }^{\circ} \mathrm{C}$ and (e) Ca-P coating on a titanium layer annealed to $800{ }^{\circ} \mathrm{C}$
While the diffraction pattern shows the presence of HA with peaks corresponding closely to the ICDD file \#090432, the presence of peaks due to rutile $\mathrm{TiO}_{2}$ (ICDD file \#21-1276) are also clearly present, as shown in Fig. 3c. These rutile peaks also exhibit significant peak broadening. Peaks due to the presence of $\mathrm{Ti}_{2} \mathrm{O}$ (ICDD file \#011-0218) and TiO (ICDD file\#002-1196) may also be present, as shown on Fig. 2c, however the assignment of this peaks is not certain. After heating to $700{ }^{\circ} \mathrm{C}$, the peaks due to HA (ICDD file \#09-0432) and rutile (ICDD file \#21-1276) are again observed, as shown in Fig. 2d, however, the rutile now clearly dominates the diffraction pattern. After heating the Ca-P coating on the titanium layer to $800{ }^{\circ} \mathrm{C}$, no $\mathrm{HA}$ peaks can be detected and only the presence of rutile material can be confirmed, as shown in Fig. 2e. The peaks are again closely aligned with those observed in the ICDD file \#21-1276 for rutile. No other phases other than rutile were identified in the diffraction pattern for the coating heated to $800{ }^{\circ} \mathrm{C}$.

\section{XPS of the $\mathrm{Ca}-\mathrm{P} / \mathrm{TiO}_{2}$ coatings}

The XPS data for the uppermost surface of the Ti-6Al-4V substrate after abrasion indicates the presence of oxygen, carbon, nitrogen and sodium in addition to titanium, vanadium and aluminium as shown in Fig. 3a and Table 2. The high resolution $\mathrm{Ti} 2 \mathrm{p}$ spectrum for the Ti-6Al-4V substrate, as shown in Fig. 3b indicates the presence of $\mathrm{TiO}_{2}$ due to the peaks at $459.0 \mathrm{eV}\left(\mathrm{Ti} 2 \mathrm{p}_{3 / 2}\right)$ and at $464.5 \mathrm{eV}\left(\mathrm{Ti} 2 \mathrm{p}_{1 / 2}\right)$ [33-35]. In addition to these, the peak observed at $453.5 \mathrm{eV}$ (Ti2 $\mathrm{p}_{3 / 2}$ ) would normally be associated with metallic titanium [34]. The presence of this surface oxide layer is confirmed by the nature of the high resolution $\mathrm{O} 1 \mathrm{~s}$ spectral envelope as shown in Fig. 3c, which clearly shows a strong contribution from $\mathrm{TiO}_{2}$ at $530.5 \mathrm{eV}$ [35]. The shoulder on the high B.E. side of the O1s peak at $530.5 \mathrm{eV}$ as shown in Fig. 3c may be a consequence of the presence of oxygen from organic species and/or $\mathrm{OH}$ groups [35, 36]. A similar set of results were observed for the titanium layer. However, the contribution from the $\mathrm{TiO}_{2}$ peaks $\left(458.80 \mathrm{eV}\left(\mathrm{Ti} 2 \mathrm{p}_{3 / 2}\right)\right.$ and at $\left.464.7 \mathrm{eV}\left(\mathrm{Ti}_{2} \mathrm{p}_{1 / 2}\right)\right)$ are more dominant than that for the metallic peak $453.6 \mathrm{eV}\left(\mathrm{Ti} 2 \mathrm{p}_{3 / 2}\right)$ in the Ti2p high resolution spectrum. By comparison, the XPS data for the titanium layer annealed at $800{ }^{\circ} \mathrm{C}$ shows only the presence of $\mathrm{TiO}_{2}$ in the $\mathrm{Ti} 2 \mathrm{p}$ spectral envelope, as given by the peaks at 458.9.0 eV $\left(\mathrm{Ti} 2 \mathrm{p}_{3 / 2}\right)$ and at $464.4 \mathrm{eV}\left(\mathrm{Ti} 2 \mathrm{p}_{1 / 2}\right)$ [33-35]. The corresponding $\mathrm{O} 1 \mathrm{~s}$ spectral envelope after heating to $800{ }^{\circ} \mathrm{C}$ confirms the oxide nature of the surface due to the presence of a strong peak at $530.3 \mathrm{eV}\left(\mathrm{TiO}_{2}\right)$ [35] and a significant shoulder on the high B.E. side of the peak $(\sim 532.4 \mathrm{eV})$. As described previously, this shoulder is normally associated with oxygen from organic species and/ or $\mathrm{OH}$ groups $[35,36]$. 
Fig. 3 XPS spectra of (a) wide energy survey scan $(0$ $1300 \mathrm{eV}),(\mathbf{b}) \mathrm{Ti} 2 \mathrm{p}$ spectral envelope and (c) O1s spectral envelope for the Ti-6Al-4V substrate (abraded)

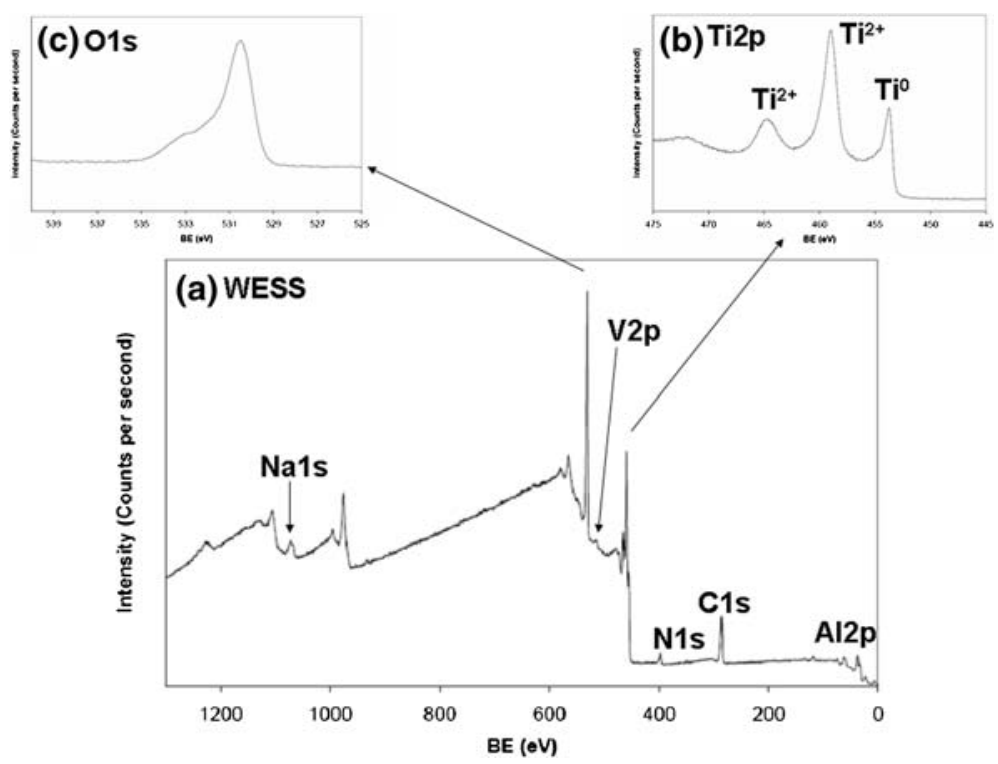

Table 2 XPS data for HA precursor powder, titanium, $\mathrm{TiO}_{2}$, Ca-P and $\mathrm{Ca}-\mathrm{P} / \mathrm{TiO}_{2}$ coatings

\begin{tabular}{|c|c|c|c|c|c|c|c|c|c|}
\hline \multirow[t]{2}{*}{ Sample } & \multicolumn{8}{|c|}{ Peak position (binding energy) $\mathrm{eV}^{*}$} & \multirow[t]{2}{*}{$\mathrm{Ca} / \mathrm{P}$} \\
\hline & $\mathrm{C} 1 \mathrm{~s}$ & $\mathrm{O} 1 \mathrm{~s}$ & $\mathrm{Ca} 2 \mathrm{p}_{3 / 2}$ & $\mathrm{P} 2 \mathrm{p}$ & $\mathrm{Ti} 2 \mathrm{p}_{3 / 2}$ & $\mathrm{~V} 2 \mathrm{p}_{3 / 2}$ & $\mathrm{~A} 12 \mathrm{p}_{3 / 2}$ & $\mathrm{Na} 1 \mathrm{~s}$ & \\
\hline HA Powder & 285.0 & 531.2 & 347.3 & 133.3 & I & l & l & I & $1.63 \pm 0.02$ \\
\hline Ti-6Al-4V & 285.0 & 530.5 & l & I & 459.0 & 512.3 & 72.7 & 1072.1 & l \\
\hline Ti-6Al-4V + titanium layer & 285.0 & 530.2 & l & l & 458.8 & l & l & l & l \\
\hline Ti-6Al-4V + titanium layer $\left(800^{\circ} \mathrm{C}\right)$ & 285.0 & 530.3 & l & l & 458.9 & l & l & l & l \\
\hline Ti-6Al-4V + Ca-P coating as-received & 285.0 & 531.3 & 347.7 & 133.4 & l & l & l & / & $1.35 \pm 0.03$ \\
\hline $\mathrm{Ti}-6 \mathrm{Al}-4 \mathrm{~V}+$ titanium layer $+\mathrm{Ca}-\mathrm{P}$ coating $\left(500^{\circ} \mathrm{C}\right)$ & 285.0 & 531.6 & 347.5 & 132.8 & I & l & l & l & $2.24 \pm 0.03$ \\
\hline Ti-6Al-4V + titanium layer $+\mathrm{Ca}-\mathrm{P}$ coating as received & 285.0 & 531.3 & 347.4 & 133.5 & I & l & l & l & $1.42 \pm 0.05$ \\
\hline Ti-6Al-4V + titanium layer + Ca-P coating $\left(500^{\circ} \mathrm{C}\right)$ & 285.0 & 531.7 & 347.5 & 133.4 & I & l & l & l & $2.47 \pm 0.08$ \\
\hline $\mathrm{Ti}-6 \mathrm{Al}-4 \mathrm{~V}+$ titanium layer $+\mathrm{Ca}-\mathrm{P}$ coating $\left(600^{\circ} \mathrm{C}\right)$ & 285.0 & 531.7 & 347.7 & 133.5 & l & l & l & l & $1.92 \pm 0.06$ \\
\hline Ti-6Al-4V + titanium layer $+\mathrm{Ca}-\mathrm{P}$ coating $\left(700^{\circ} \mathrm{C}\right)$ & 285.0 & 531.7 & 347.8 & 133.6 & 459.0 & l & l & l & $1.82 \pm 0.07$ \\
\hline Ti-6Al-4V + Ca-P coating $\left(800^{\circ} \mathrm{C}\right)$ & 285.0 & 530.3 & 347.5 & 133.5 & 458.8 & l & l & I & $0.51 \pm 0.18$ \\
\hline
\end{tabular}

* Most intense photoelectron line for each element detected

In comparison to these results, the XPS data for the asdeposited Ca-P coating on Ti-6Al-4V, given in Table 2, indicates similar peaks to those observed the HA precursor powder. Peak lines corresponding to $\mathrm{Ca}_{2} \mathrm{p}_{3 / 2}(347.7 \mathrm{eV})$, P2p $(133.4 \mathrm{eV}), \mathrm{O} 1 \mathrm{~s}(531.3 \mathrm{eV})$, are clearly present, as before. The $\mathrm{Ca} / \mathrm{P}$ ratio of the as-deposited $\mathrm{Ca} / \mathrm{P}$ coatings was $1.35 \pm 0.03$ as reported in Table 2 , a value slightly lower than expected for stoichiometric HA (1.67) [37]. Similar peak positions are also observed for the Ca-P coating after annealing to $500{ }^{\circ} \mathrm{C}$, however, the $\mathrm{Ca} / \mathrm{P}$ ratio of the coatings was seen to increase significantly to $2.24 \pm 0.03$, as shown in Table 2. No titanium peaks from the underlying substrate were detected in any of the Ca-P coatings deposited directly onto the Ti-6Al-4V substrate. The XPS data for the Ca-P coatings deposited onto the titanium layer, as illustrated in Fig. 4 (as-deposited) and
Fig. 5 (annealed at $500^{\circ}$ ) showed very similar results when compared to those deposited directly onto the Ti-6Al-4V substrate. The as-deposited coating on the titanium layer gave a $\mathrm{Ca} / \mathrm{P}$ ratio of $1.42 \pm 0.05$, whereas the coating annealed to $500{ }^{\circ} \mathrm{C}$, gave a much higher $\mathrm{Ca} / \mathrm{P}$ ratio of $2.47 \pm 0.08$, as reported in Table 2. After annealing the Ca-P coating deposited onto the titanium layer to $600{ }^{\circ} \mathrm{C}$, the $\mathrm{Ca} / \mathrm{P}$ ratio decreased significantly to $1.92 \pm 0.06$. No titanium from the layer could be detected in these Ca-P coatings annealed to $500{ }^{\circ} \mathrm{C}$ or $600{ }^{\circ} \mathrm{C}$. However, after annealing the Ca-P coatings deposited onto the titanium layer to $700{ }^{\circ} \mathrm{C}$, significant differences were observed and a weak Ti2p peak was detected as shown in Ti2p high resolution envelope in Fig. 6a. The distribution of peaks in the Ti2p envelope for this coating indicates the presence of $\mathrm{TiO}_{2}$ with peaks at $459.0 \mathrm{eV}\left(\mathrm{Ti} 2 \mathrm{p}_{3 / 2}\right)$ and at $464.5 \mathrm{eV}$ 
Fig. 4 XPS spectra of (a) C1s, (b) O1s, (c) Ca2p and (d) P2p regions for the as-received $\mathrm{Ca}-\mathrm{P}$ coating on a titanium layer
Fig. 5 XPS spectra of (a) C1s, (b) $\mathrm{O} 1 \mathrm{~s}$, (c) $\mathrm{Ca} 2 \mathrm{p}$ and (d) $\mathrm{P} 2 \mathrm{p}$ regions for the Ca-P coating on a titanium layer annealed to $500{ }^{\circ} \mathrm{C}$
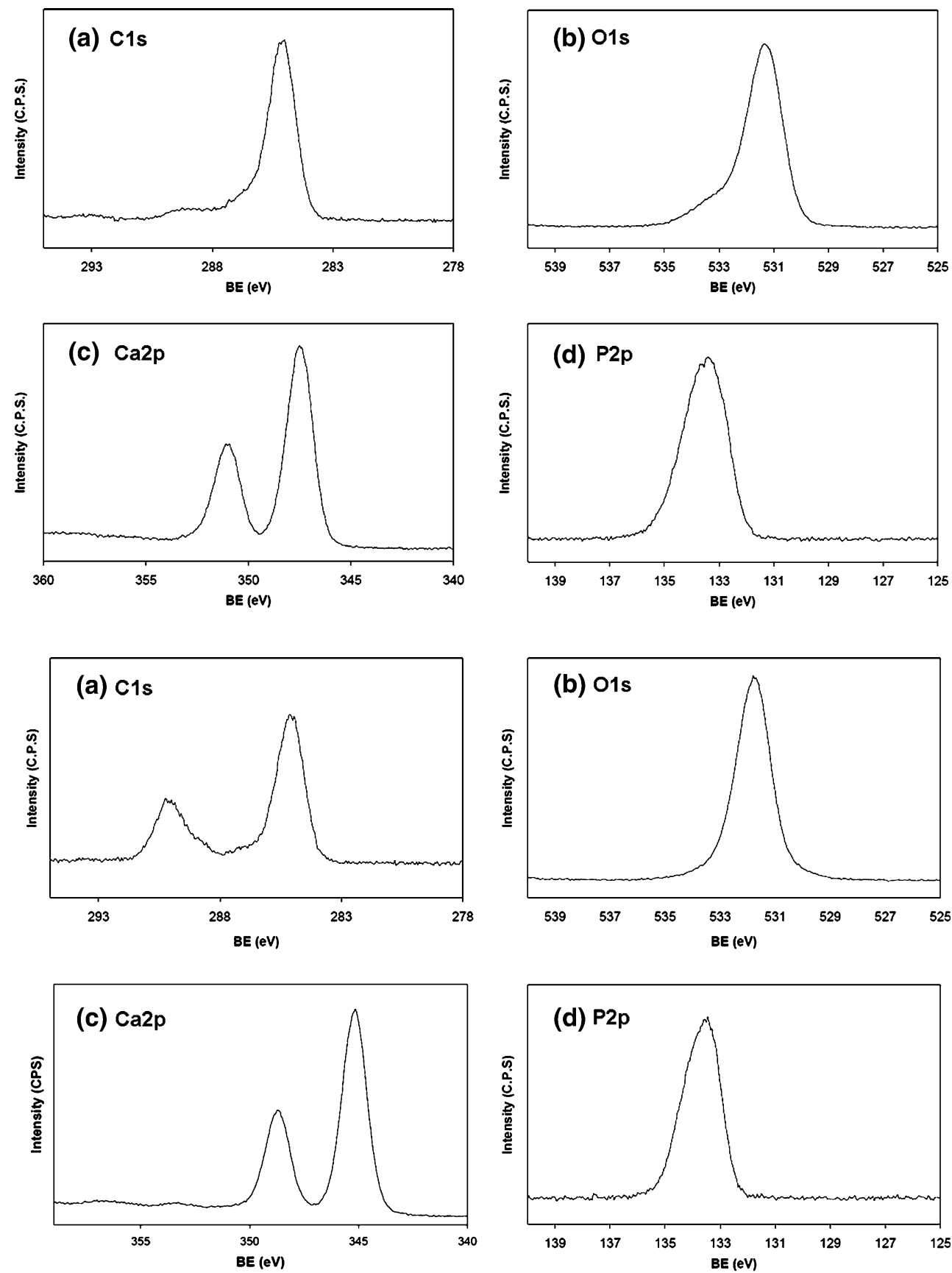

(Ti2 $\mathrm{p}_{1 / 2}$ ) [33-35]. In addition to the presence of an oxide layer, calcium $(\mathrm{Ca} 2 \mathrm{p})$ and phosphorus $(\mathrm{P} 2 \mathrm{p})$ were also detected on the uppermost surface of this coating as shown in Table 2 and Fig $6 c, d$ respectively. The $\mathrm{Ca} / \mathrm{P}$ ratio again decreased to a value of $1.82 \pm 0.07$. After annealing the Ca-P coating deposited onto the titanium layer to $800{ }^{\circ} \mathrm{C}$, a significant oxide layer appears to develop at the surface of the coating, as shown in Fig. 7a, b and Table 2. The high resolution Ti2p spectrum for the coating annealed to $800{ }^{\circ} \mathrm{C}$, as shown in Fig. 7 a, indicates the presence of $\mathrm{TiO}_{2}$ due to the significant peaks at $458.8 \mathrm{eV}\left(\mathrm{Ti}_{2} \mathrm{p}_{3 / 2}\right)$ and at $464.6 \mathrm{eV}\left(\mathrm{Ti} 2 \mathrm{p}_{1 / 2}\right)$ [33-35]. In addition to these, the weak band at $453.8 \mathrm{eV}\left(\mathrm{Ti} 2 \mathrm{p}_{3 / 2}\right)$ can be attributed to metallic titanium [34]. The presence of this surface oxide layer is confirmed by the nature of the high resolution O1s spectral envelope, as shown in Fig. 7b, which clearly illustrates a contribution from $\mathrm{TiO}_{2}(530.3 \mathrm{eV})$. The significant shoulder at higher binding energy in the O1s peak is most likely a consequence of oxygen from organic species and $\mathrm{OH}$ groups, as described previously. However, this coating also shows the presence of low levels of calcium $(\mathrm{Ca} 2 \mathrm{p})$ and phosphorus (P2p), as shown in Table 2 and Fig. 7c, d respectively. The $\mathrm{Ca} / \mathrm{P}$ ratio for this coating was $0.51 \pm 0.18$, which is due to the fact that the $\mathrm{TiO}_{2}$ 
Fig. 6 XPS spectra of (a) Ti2p, (b) O1s, (c) Ca2p and (d) P2p regions for a $\mathrm{Ca}-\mathrm{P}$ coating on a titanium layer annealed to $700{ }^{\circ} \mathrm{C}$
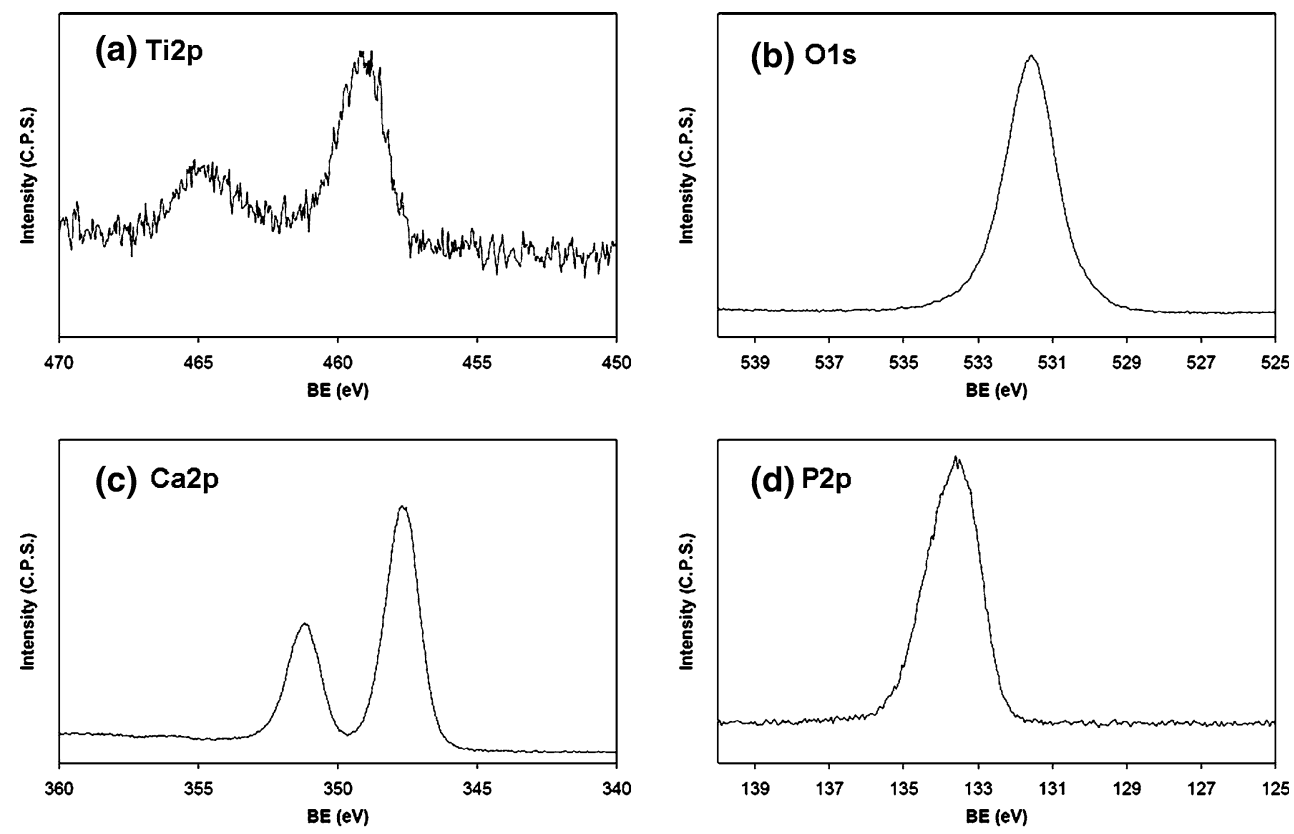

dominates the uppermost surface of the $800{ }^{\circ} \mathrm{C}$ annealed coating.

\section{SEM of the $\mathrm{Ca}-\mathrm{P} / \mathrm{TiO}_{2}$ coatings}

SEM analysis of the abraded Ti-6Al-4V substrate shows a surface that has random abrasion scratches running across its surface (not shown here). These abrasion scratches dominate the substrate surface and can range in width from 0.3-2.0 $\mu \mathrm{m}$. Small hillocks, pits and fissures, which vary in size up to $5.0 \mu \mathrm{m}$, are also seen regularly across the surface, particularly between the polishing scratches. For the
Ti-6Al-4V substrate coated with a titanium layer, titanium crystallites are up to $150 \mathrm{~nm}$ in diameter and seem to have formed preferentially around the more prominent surface asperities on the substrate, as illustrated in Fig. 8a. In addition to this, the formation of larger spherical shape features of up to $2 \mu \mathrm{m}$ are clearly evident. It is also apparent from the SEM results that there has been significant in-filling of the larger pits and abrasion scratches on the substrate surface. After annealing this coating to $800{ }^{\circ} \mathrm{C}$, as shown in Fig. $8 \mathrm{~b}$ the uppermost surface exhibits a needle-like morphology, with the needles having random orientation and a long axis dimension of up to $1.0 \mu \mathrm{m}$.
Fig. 7 XPS spectra of (a) Ti2p, (b) O1s, (c) Ca2p and (d) P2p regions for a $\mathrm{Ca}-\mathrm{P}$ coating on a titanium layer annealed to $800{ }^{\circ} \mathrm{C}$
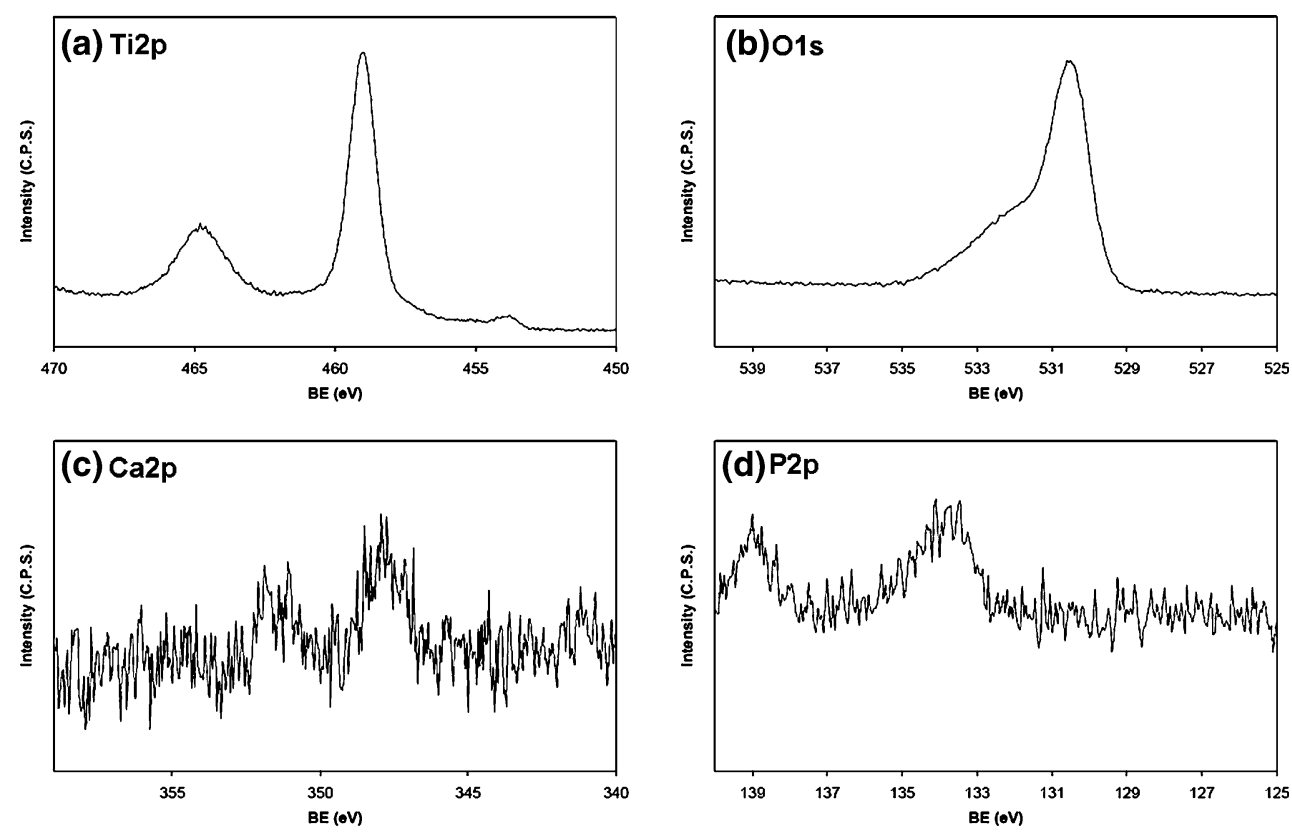
The corresponding SEM results for the as-deposited $\mathrm{Ca}$ $\mathrm{P}$ coating on the Ti-6Al-4V substrate shows a relative tendency for the coatings to mimic the substrate topography and to conform to striations and defects produced by the abrasion of the substrate. Again, there is evidence from the SEM to suggest that there has been significant in-filling of the larger pits on the substrate surface, which is typical of previous studies utilising similar RF magnetron sputter deposited calcium phosphate coatings [13]. On annealing, this coating to $500{ }^{\circ} \mathrm{C}$ the coating surface appears to transform from a smooth coherent film into one that exhibits columnar features across the coating surface and range in size from $0.5-1.0 \mu \mathrm{m}$. By comparison, the SEM data for as-deposited Ca-P coating on the titanium layer also appears to mimic the topography of the underlying surface, as shown in Fig. 8c. These results are similar to those observed for the as-deposited $\mathrm{Ca}-\mathrm{P}$ coating on the $\mathrm{Ti}$ $6 \mathrm{Al}-4 \mathrm{~V}$ substrate. However, after annealing the Ca-P coating on the titanium layer to $500{ }^{\circ} \mathrm{C}$ the surface appears to have formed a smooth, dense and coherent layer, with spherical features of up to $2.0 \mu \mathrm{m}$ evident around abrasion scratches and surface defects, as illustrated in Fig. 8d. After annealing to $600{ }^{\circ} \mathrm{C}$, this coating has transformed into one that exhibits large spherical features that are between $0.5-2.0 \mu \mathrm{m}$. Some of these also appear to have coalesced into larger spherical features of up to $5 \mu \mathrm{m}$ across. Also apparent is the obvious micro-cracking along the surface of these larger raised spherical objects. After annealing to $700{ }^{\circ} \mathrm{C}$, there is further significant change in the substrate morphology, with chains of micro-crystallites of up to $0.5 \mu \mathrm{m}$ forming along the lines of microcracks. This is clearly shown in Fig. 8e. After annealing the Ca-P coating on the titanium layer to $800{ }^{\circ} \mathrm{C}$, as illustrated in Fig. 8f the surface morphology shows a distinct similarity to that observed for the titanium layer after heating to $800{ }^{\circ} \mathrm{C}$, with an obvious needle-like morphology.

Cell attachment, spreading, and morphology

Cells appeared to adhere and spread successfully to all of the samples analysed using the cell tracker green assay at a time period of $1 \mathrm{~h}$. Figure $9 \mathrm{a}, \mathrm{b}$ show the results for the Ti-6Al-4V abraded substrate (control) and the Ca-P coating deposited onto the titanium layer and annealed to $700{ }^{\circ} \mathrm{C}$. No significant differences were observed between the various samples in relation to their cell morphology, and for each sample the cells exhibited normal cell morphology. In all cases distinct adhesion sites could be clearly observed.
Fig. 8 SEM micrographs of (a) titanium layer on Ti-6Al-4V substrate, (b) titanium layer on Ti-6Al-4V substrate and annealed to $800{ }^{\circ} \mathrm{C}$, (c) $\mathrm{Ca}-\mathrm{P}$ coating on titanium layer and annealed to $500{ }^{\circ} \mathrm{C}$, (d) $\mathrm{Ca}-\mathrm{P}$ coating on a titanium layer and annealed to $600{ }^{\circ} \mathrm{C}$, (e) Ca-P coating on a titanium layer and annealed to $700{ }^{\circ} \mathrm{C}$ and (f) $\mathrm{Ca}-\mathrm{P}$ coating on a titanium layer and annealed to $800{ }^{\circ} \mathrm{C}$ (all at $3000 \times$ magnification)
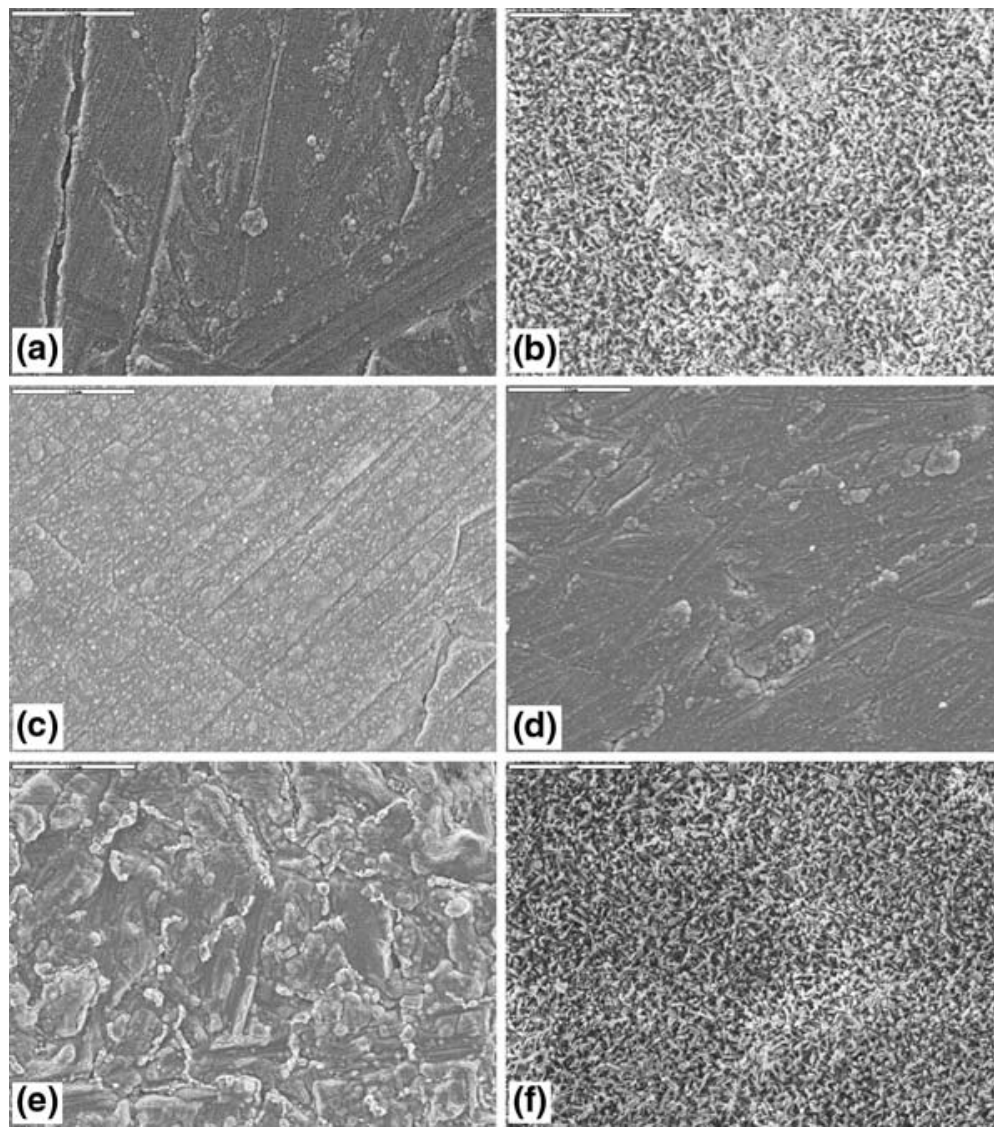


\section{Cell proliferation}

The results for the MTT assay on the various different surfaces showed that the adherent cells proliferated on all of the samples investigated. At the $24 \mathrm{~h}$ assay time-point, only the Ca-P coating deposited onto the titanium layer and annealed to $700{ }^{\circ} \mathrm{C}$ exhibited a significant increase in the cell proliferation as shown in Fig. 10. Each value is reported as the mean \pm S.D. of three independent experiments. The asterisk indicates a significant difference between the control and surface treated groups, as analysed by ANOVA and Dunnett's test post-hoc $(p<0.05)$. No other surface exhibited any significant effects on cell proliferation at this time. However, after the $72 \mathrm{~h}$ assay timepoint the effect of the different surfaces on cell proliferation was significantly altered as shown in Fig. 10. Both the titanium layer annealed to $800{ }^{\circ} \mathrm{C}$ and the Ca-P coating deposited onto the titanium layer and annealed to $800{ }^{\circ} \mathrm{C}$ exhibited a significant decrease in cell proliferation when compared to the control sample. By comparison, the Ca-P coating deposited onto the Ti-6Al-4V substrate and annealed to $500{ }^{\circ} \mathrm{C}$ and the $\mathrm{Ca}-\mathrm{P}$ coating deposited onto the
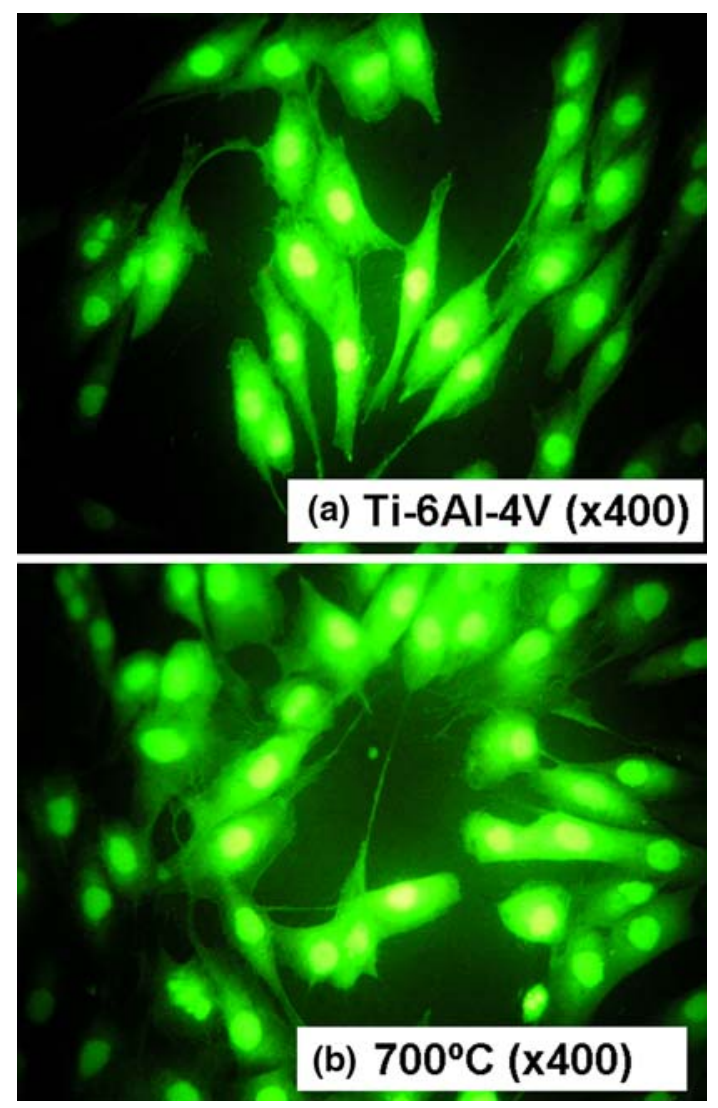

Fig. 9 Fluorescence microscope images of MG63 osteoblast-like cells after $1 \mathrm{~h}$ attachment assay (cell tracker green) on (a) Ti-6Al-4V substrate (abraded) and (b) Ca-P coating on a titanium layer annealed to $700{ }^{\circ} \mathrm{C}$ titanium layer and annealed to $700{ }^{\circ} \mathrm{C}$ induced a significant increase in MG-63 osteoblast cell proliferation in relation to the control. In particular, the latter of these coatings exhibited the most significant increase in cell proliferation at this time-point. The cell proliferation for the Ca-P coating deposited onto the titanium layer and annealed to $500{ }^{\circ} \mathrm{C}$ was not significantly different from the control Ti-6Al-4V substrate after $72 \mathrm{~h}$.

\section{Discussion}

The purpose of this work was to produce and study a range of $\mathrm{RF}$ magnetron sputter deposited $\mathrm{Ca}-\mathrm{P} / \mathrm{TiO}_{2}$ hybrid coatings on medical grade Ti-6Al-4V substrates.

As in the case of previous studies, which have also utilised RF magnetron sputtering at relatively low sputtering powers $(<150 \mathrm{~W})$ to deposit Ca-P thin films, the asdeposited coatings were amorphous in nature as demonstrated by the XRD data [13, 36]. This phenomena was clearly observed for the as-deposited Ca-P coatings on both the abraded Ti-6Al-4V substrates and the titanium coated Ti-6Al-4V substrates. These same coatings were also seen to be poorly hydroxylated, as shown in the corresponding FTIR spectra, which clearly lacked the expected HA O-H vibrational modes at $3,570 \mathrm{~cm}^{-1}$ and $630 \mathrm{~cm}^{-1}[23,29,30]$. The $\mathrm{Ca} / \mathrm{P}$ ratios for the same surfaces determined by XPS, were $1.35 \pm 0.03$ and $1.42 \pm 0.05$, respectively, values much lower than would be expected for stoichiometric HA at 1.67 [28]. By comparision, these values were also much lower than those obtained for similar studies $[13,36]$ which

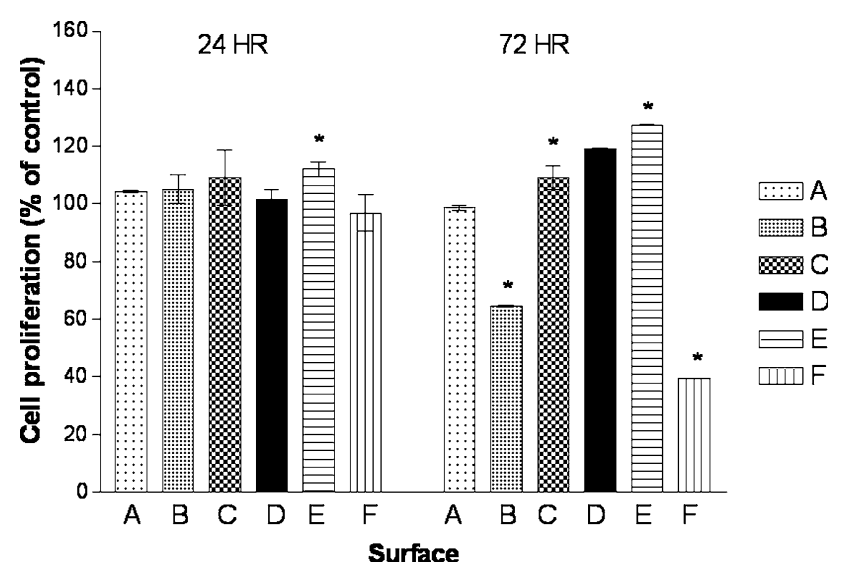

Fig. 10 MTT results of MG63 cell proliferation on Ca-P and Ca-P/ $\mathrm{TiO}_{2}$ surfaces after $24 \mathrm{~h}$ and $72 \mathrm{~h}$ incubation time $(* p<0.05)$ Key for Fig. 10: A-Ti-6Al-4V substrate (control), B-Ti-6Al-4V + titanium layer annealed to $800{ }^{\circ} \mathrm{C}, \mathrm{C}-\mathrm{Ti}-6 \mathrm{Al}-4 \mathrm{~V}+\mathrm{Ca}-\mathrm{P}$ outer layer annealed to $500{ }^{\circ} \mathrm{C}, \mathrm{D}-\mathrm{Ti}-6 \mathrm{Al}-4 \mathrm{~V}+$ titanium layer $+\mathrm{Ca}-\mathrm{P}$ outer layer annealed to $500{ }^{\circ} \mathrm{C}$, E-Ti-6Al-4V + titanium layer + Ca-P outer layer annealed to $700{ }^{\circ} \mathrm{C}$ and $\mathrm{F}-\mathrm{Ti}-6 \mathrm{Al}-4 \mathrm{~V}+$ titanium layer + Ca-P outer layer annealed to $800{ }^{\circ} \mathrm{C}$ 
deposited Ca-P coatings from the same source material (Merck KGaA, Darmstadt, Germany) using single sputtering targets rather than three (as employed for this work). It should also be noted that the three sputtering sources in this study were mounted at a $45^{\circ}$ angle to the substrate surfaces, whereas the single sputtering target previously was mounted axially to the substrates [13, 36]. It is therefore possible, that the experimental conditions employed during deposition for this study may have had a significant impact on the dynamics of the sputtering process, and as a consequence, the $\mathrm{Ca} / \mathrm{P}$ ratio of the resultant as-deposited Ca-P coatings. It is suggested that the arrangement and orientation of the sputtering sources and the argon gas pressure employed during this study may have been the main contributing factors that influenced the energetic interactions within the plasma and the thermodynamics of the nucleation and growth phenomenon at the substrate surface. To date, the authors have been unable to find any published work, which utilises the same experimental set-up to deposit $\mathrm{Ca}-\mathrm{P} / \mathrm{TiO}_{2}$ surfaces. In addition to this, the plasma conditions utilised in these experiments have not yet been fully characterised, therefore this hypothesis cannot be confirmed. Previous studies by others have described how various different aspects of the sputtering process can significantly influence the $\mathrm{Ca} / \mathrm{P}$ ratio, such as argon gas pressure [7], bias voltage [33], discharge power level [20], the presence of oxygen species [37] and thermal processing [13, 38, 39].

Upon annealing the Ca-P coatings on both the abraded Ti-6Al-4V substrates and the titanium coated Ti-6Al-4V substrates to $500{ }^{\circ} \mathrm{C}$, the FTIR and XRD data clearly show distinct differences when compared to the same coatings, as deposited. The XRD results provide direct evidence for a significant improvement in the crystallinity of the coatings. This improvement in the crystallinity of the coating coincides with the increased hydroxylation of the coating, as observed in the corresponding FTIR spectra. It has been documented that the scale of ordering in HA materials is a consequence of the degree of hydroxylation, which is highly influential in determining the physiological behaviour of the material [40]. In addition to this the XRD and FTIR data do not indicate the presence of any other $\mathrm{Ca}-\mathrm{P}$ phases in these coatings annealed to $500{ }^{\circ} \mathrm{C}$. Significantly, the $\mathrm{Ca} / \mathrm{P}$ ratios for both the annealed coatings on the abraded Ti-6Al-4V substrates and on the titanium coated Ti-6Al-4V substrates are seen to increase to $2.24 \pm 0.03$ and $2.47 \pm 0.08$, respectively, which is very close to the values obtained in similar studies $[13,36]$. This significant increase in the $\mathrm{Ca} / \mathrm{P}$ ratio to produce a calcium rich surface is most likely due to the evaporation of volatile phosphorus products during thermal annealing $[13,36]$. In addition to these findings, the peaks observed between $1,600-1,400 \mathrm{~cm}^{-1}$ and at $879 \mathrm{~cm}^{-1}$ in the FTIR data for the annealed coatings on the titanium coated Ti-6Al-4V substrates annealed at $500{ }^{\circ} \mathrm{C}$ indicates the presence of $\mathrm{CO}_{3}^{2-}$ [29]. Further evidence for this is provided by the strong peak in the $\mathrm{C} 1 \mathrm{~s}$ envelope $(289.0 \mathrm{eV})$ for the same coating, which is normally associated with the presence of $\mathrm{CO}_{3}^{2-}$ species [41].

As the post-deposition processing temperature is increased to $600{ }^{\circ} \mathrm{C}$ and then $700{ }^{\circ} \mathrm{C}$, there is a significant decrease in the $\mathrm{Ca} / \mathrm{P}$ ratio of the coatings to $1.92 \pm 0.06$ and $1.82 \pm 0.07$, respectively. This decrease in the stoichiometry of the Ca-P surfaces (compared to the coatings heated to $500{ }^{\circ} \mathrm{C}$ ) coincides with a significant increase in the hybrid nature of the coatings, which clearly show the presence of both $\mathrm{HA}$ and $\mathrm{TiO}_{2}$ materials. The XRD data confirms this, whereby the coating that was annealed at $600{ }^{\circ} \mathrm{C}$ is shown to contain both $\mathrm{HA}$ and rutile $\mathrm{TiO}_{2}$ simultaneously, with peaks corresponding closely to the ICDD file \#09-0432 (HA) and ICDD file \#21-1276 (Rutile $\mathrm{TiO}_{2}$ ), respectively. Despite this, there was no evidence from the XPS data to suggest the presence of $\mathrm{TiO}_{2}$ in the uppermost surface layer $(\sim 5 \mathrm{~nm})$ of this coating after heating to $600{ }^{\circ} \mathrm{C}$. In contrast to this, the XPS results for the coatings annealed at $700{ }^{\circ} \mathrm{C}$ clearly show that this HA/ $\mathrm{TiO}_{2}$ hybrid condition is present, even in the uppermost surface. Evidence for this is provided by the distribution of peaks indicative of $\mathrm{TiO}_{2}\left(459.0 \mathrm{eV}\left(\mathrm{Ti} 2 \mathrm{p}_{3 / 2}\right)\right.$ and at $\left.464.5 \mathrm{eV}\left(\mathrm{Ti} 2 \mathrm{p}_{1 / 2}\right)\right)$ in the $\mathrm{Ti} 2 \mathrm{p}$ high resolution envelope for the surfaces annealed to $700{ }^{\circ} \mathrm{C}$.

The XRD data for the coatings heated to $800{ }^{\circ} \mathrm{C}$ shows the presence of rutile $\mathrm{TiO}_{2}$ (ICDD file \#21-1276) but does not indicate the presence of any HA (or any other Ca-P phases). Despite this it should be noted that low levels of both calcium $(\mathrm{Ca} 2 \mathrm{p})$ and phosphorus $(\mathrm{P} 2 \mathrm{p})$ were detected in the uppermost surface of coatings heated to $800{ }^{\circ} \mathrm{C}$ using XPS analysis, however they could not be assigned to any particular Ca-P phase as they were not detected in the XRD results at this temperature. The XPS data also confirmed a further significant decrease in the $\mathrm{Ca} / \mathrm{P}$ ratio to $0.51 \pm 0.18$ for these coatings heated to $800{ }^{\circ} \mathrm{C}$. The Ti2p and O1s spectral envelopes observed for the XPS data for these surfaces confirms the presence of $\mathrm{TiO}_{2}$ in the uppermost surface layer, which corroborates the XRD data. These results clearly show that the $\mathrm{TiO}_{2}$ dominates the uppermost surface of the coatings heated to $800{ }^{\circ} \mathrm{C}$. Throughout this study no chemical products from HA or $\mathrm{TiO}_{2}$ (such as $\mathrm{CaTiO}_{3}$ ), were detected after annealing any of the coatings between 500 and $800{ }^{\circ} \mathrm{C}$. This is similar to results observed in other studies, where such products were only observed in $\mathrm{HA} / \mathrm{TiO}_{2}$ composite coatings after thermal processing at temperatures above $700{ }^{\circ} \mathrm{C}[18,42]$. This may also be a consequence of the fact that only the rutile phase of $\mathrm{TiO}_{2}$ was detected in the coatings produced during this study and it has been suggested that HA may react preferentially with anatase rather than rutile [43]. 
The significant decrease in the $\mathrm{Ca} / \mathrm{P}$ of the coatings with increasing heating temperature observed during these experiments is most likely a direct consequence of the evaporation of volatile phosphorus products during thermal processing [13] rather than a significant increase in the hybrid nature of the coatings up to annealing temperatures of $600{ }^{\circ} \mathrm{C}$. This is due to the fact that no $\mathrm{TiO}_{2}$ was detected in the uppermost surface of the coatings annealed up to $600{ }^{\circ} \mathrm{C}$. However, the diffusion of $\mathrm{TiO}_{2}$ through the HA surfaces of the coatings during heating may also contribute to the decreasing $\mathrm{Ca} / \mathrm{P}$ ratio with increasing temperature at the higher annealing temperatures (700 and $\left.800{ }^{\circ} \mathrm{C}\right)$. Therefore, its influence on this phenomenon cannot be ruled out. Indeed, it has been suggested that the incorporation of $\mathrm{TiO}_{2}$ into the HA coating can result in its decomposition to tri-calcium phosphate (TCP) during thermal annealing [43]. However, this was not observed during this study.

From these results, and especially the XPS data, it is evident that the uppermost surface $(\sim 5 \mathrm{~nm})$ of the coatings annealed at $500{ }^{\circ} \mathrm{C}$ and $600{ }^{\circ} \mathrm{C}$ are dominated by $\mathrm{HA}$, whereas the coatings annealed at $800{ }^{\circ} \mathrm{C}$ are dominated by rutile $\mathrm{TiO}_{2}$. Only the coatings thermally processed at $700{ }^{\circ} \mathrm{C}$ exhibit a hybrid $\mathrm{HA} / \mathrm{TiO}_{2}$ nature in this uppermost surface region $(\sim 5 \mathrm{~nm})$. In this regard, it is important that the properties of the uppermost surface are optimised for biological performance (along with the bulk properties of the material), as it has been well documented that it is the uppermost surface that forms the biological interface and guides and modulates the initial cellular response [44]. For this study the initial cellular attachment, spreading and morphology of MG63 osteoblast-like cells on the various coatings produced was investigated after $1 \mathrm{~h}$ using a cell tracker green assay. Cells appeared to adhere and proliferate successfully on all of the samples and no significant differences were observed between the various samples in relation to their cell morphology, with all of the cells exhibiting normal MG63 osteoblast cell morphology. Cell proliferation was studied using an MTT assay at two different time points ( $24 \mathrm{~h}$ and $72 \mathrm{~h}$ ). The results for the MTT assay on the various different surfaces showed that the MG63 cells proliferated on all of the samples investigated. At the $24 \mathrm{~h}$ assay time-point, only the Ca-P coating deposited onto the titanium layer and thermally processed to $700{ }^{\circ} \mathrm{C}$ exhibited significant effects on cell growth No other surface exhibited any significant effects on cell proliferation after $24 \mathrm{~h}$. However, after the $72 \mathrm{~h}$ assay timepoint the effect of the different surfaces on cell proliferation was significantly altered. First, all of the coatings annealed at $800{ }^{\circ} \mathrm{C}$, which were predominantly rutile $\mathrm{TiO}_{2}$, exhibited a significant decrease in cell proliferation when compared to the control sample. By comparison, the Ca-P coating deposited onto the Ti-6Al-4V substrate and annealed to $500{ }^{\circ} \mathrm{C}$ and the $\mathrm{Ca}-\mathrm{P}$ coating deposited onto the titanium layer and annealed to $700{ }^{\circ} \mathrm{C}$ induced a significant increase in MG-63 osteoblast cell proliferation in relation to the control. In particular, the latter of these coatings exhibited the most significant increase in cell proliferation at this time-point. It is therefore evident from these MTT data that for both time points studied, the coating thermally annealed to $700{ }^{\circ} \mathrm{C}$ is best suited to support osteoblast-like cell proliferation when compared to the control. This includes the coatings that were annealed to $800{ }^{\circ} \mathrm{C}$, which were predominantly rutile $\mathrm{TiO}_{2}$ in nature and the coatings annealed to $500{ }^{\circ} \mathrm{C}$, which were predominantly $\mathrm{HA}$ in nature. This would therefore suggest that $\mathrm{HA} / \mathrm{TiO}_{2}$ hybrid surfaces have the potential to be better support osteoblast cell growth than HA coatings or rutile $\mathrm{TiO}_{2}$ surfaces alone. In previous studies by others using simulated body fluid (SBF) assays it had been well established that anatase $\mathrm{TiO}_{2}$ is better suited to induce bone formation than rutile $\mathrm{TiO}_{2}$ $[45,46]$. However, $\mathrm{Wu}$ et al. found that crystalline titania films exhibited similar in vitro bioactivity, regardless of the fraction of rutile or anatase phases [47]. In this study a significant improvement in oseteoblast proliferation is observed (when compared to HA surfaces and the Ti-6Al-4V control). This is despite the fact that the hybrid surface exhibits a strong contribution from rutile $\mathrm{TiO}_{2}$. No anatase $\mathrm{TiO}_{2}$ was observed in any of the coatings produced during this study and is a direct consequence of the temperatures employed to anneal the samples here. The exact mechanism and reason why the hybrid $\mathrm{HA} / \mathrm{TiO}_{2}$ surfaces better supported the growth of the osteoblast cells is most likely a consequence of the enhanced stability that is introduced by the incorporation of $\mathrm{TiO}_{2}$ into the HA coatings, allowing the cells to adhere and proliferate more readily. This phenomenon has been well documented in previous studies by others [48, 49]. Furthermore, it has been shown in previous work where HA coatings were produced in a similar manner and immersed in PBS (to determine their stability), that even thermally processed HA coatings could undergo partial dissolution after only $1 \mathrm{~h}$ of immersion [13]. This is most likely due to the fact that these coatings contain amorphous and less stable Ca-P phases in addition to the crystalline HA portion, which can dissolve more readily in vitro and in vivo [8, 13]. This instability may have a direct effect on the adhesion of cells to the surface in the early stages (up to $24 \mathrm{~h}$ ) and their subsequent growth and proliferation up to $72 \mathrm{~h}$. However, the immersion behaviour and stability of these coatings has not yet been investigated in order to confirm this hypothesis.

\section{Conclusion}

A series of $\mathrm{Ca}-\mathrm{P} / \mathrm{TiO}_{2}$ hybrid have been prepared by sequential sputter deposition of a titanium and $\mathrm{Ca}-\mathrm{P}$ layer 
and post deposition annealing at temperatures between $500{ }^{\circ} \mathrm{C}$ and $800{ }^{\circ} \mathrm{C}$. It has been shown that the resultant coatings have properties dependent on the annealing temperatures and that $700{ }^{\circ} \mathrm{C}$ is required to create a $\mathrm{Ca}-\mathrm{P} / \mathrm{TiO}_{2}$ hybrid syrface as determined by XPS, XRD, FTIR and SEM. In vitro characterisation of the coatings up to $72 \mathrm{~h}$ showed that the coatings thermally annealed to $700{ }^{\circ} \mathrm{C}$ supported the adhesion and proliferation of osteoblast-like cells more readily than either the HA coatings or the rutile $\mathrm{TiO}_{2}$ surfaces. This may suggest that the $\mathrm{Ca}-\mathrm{P} / \mathrm{TiO}{ }_{2}$ hybrid surfaces produced by a simple method of RF magnetron sputtering and post-deposition thermal annealing have the potential to be used as interfacial layers in order to control, and perhaps manipulate the cellular response. However, further in vitro characterisation of these surfaces is required in order to confirm these preliminary findings.

\section{References}

1. Y. LI, C. WANG, T. HAUNG, C. CHEN, C. KAO and S. DING, Surf. Coat. Tech. 197 (2005) 367

2. L. GUO and H. LI, Surf. Coat. Tech. 185 (2004) 268

3. M. TIRREL, E. KOKKOLI and M. BIESALSKI, Surf. Sci. 500 (2002) 61

4. W. F. LUI and C. S. CHEN, Mat. Today. 12 (2005) 28

5. J. G. C. WOLKE, K. VAN DIJK, H. G. SCHAEKEN, K. DE GROOT and J. A. JANSEN, J. Biomed. Mat. Res. 28 (1994) 1477

6. K. VAN DIJK, H. G. SCHAEKEN, J. G. C. WOLKE, C. H. M. MAREE, F. H. P. M. HABRAKEN, J. VERHOEVEN and J. A. JANSEN, J. Biomed. Mat. Res. 29 (1995) 269

7. K. VAN DIJK, H. G. SCHAEKEN, C. H. M. MAREE, J. VERHOEVEN, J. G. C. WOLKE, F. H. P. M. HABRAKEN and J. A. JANSEN, Surf. Coat. Tech. 76-77 (1995) 206

8. J. G. C WOLKE, J. P. C. M. VAN DER WAERDEN, H. G. SCHAEKEN and J. A. JANSEN, Biomaterials. 24 (2003) 2623

9. H. ZENG, K. K. CHITTUR and W. R. LACEFIELD, Biomaterials. 20 (1999) 443

10. H. C. GLEDHILL, I. G. TURNER and C. DOYLE, Biomaterials 22 (2001) 695

11. F. FAZAN and P. M. MARQUIS, J. Mat. Sci. Mat. Med. 11 (2000) 787

12. W. J. LO, D. M. GRANT, M. D. BALL, B. S. WELSH, S. M. HOWDLE, E. N. ANTONOV, V. N. BAGRATASHVILI and V. K. POPOV, J. Biomed. Mat. Res. 50 (2000) 536

13. A. R. BOYD, B. J. MEENAN and N. S. LEYLAND, Surf. Coat. Tech. 200 (2006) 6002

14. M. MANSO, M. LANGLET, M. FERNANDEZ, L. VASQUEZ and J. M. MARTINEZ-DUART, Mater. Sci. Eng. C. 23 (2003) 451

15. C. LIN and S. YEN, J. Mat. Sci. Mat. Med. 15 (2004) 1237

16. H. LI, K. A. KHOR and P. CHEANG, Biomaterials. 24 (2003) 949

17. E. MiLELlA, F. CONENTINO, A. LICCIULli and C. MASSARO, Biomaterials. 22 (2001) 1425

18. Y. LU, M. LI, S. LI, Z. WANG and R. ZHU, Biomaterials. 25 (2004) 4393

19. B. J. MEENAN, A. BOYD, N. S. LEYLAND, E. LOVE and M. AKAY, Bioceramics. 12 (1999) 471
20. K. OZEKI, T. YAHTA, Y. FUKUI, H. AOKI and I. NISHIMURA, J. Mat. Sci. Mat. Med. 13 (2002) 253

21. S. DING, C. JU and J. C. LIN, J. Biomed. Mat. Res. 47 (1999) 551

22. S. J. DING, C. P. JU and J. H. CHERN LIN, J. Biomed. Mat. Res. 44 (1999) 266

23. K. KONASHI, M. KAMBARA, H. NOSHI and M. UEMURA, $J$. Osaka Dent. Univ. 21 (1987) 1

24. R. C. BURGHARDT, R. BARHOUMI, E. H. LEWIS, R. H. BAILEY, K. A. PYLE, B. A. CLEMENT and T. D. PHILIPS, Toxicol. Appl. Pharmacol. 112 (1992) 235

25. N. RAIKAR, J. L. ONG and L. C. LUCAS, Surf. Sci. Spec. 4 (1997) 9

26. G. C. ALLEN, E. CILIBERTO, I. FRAGALA and G. SPOTO, Nuc. Instrum. Meth. Phys. Res. B. 116 (1996) 457

27. J. L. ONG, C. A. HOPPE, H. L. CARDENAS, R. CALVIN, D. L. CARNES, A. SOGOL and G. N. RAIKAR, J. Biomed. Mat. Res. 39 (1998) 176

28. G. WILLMANN, Brit. Cer. Trans. 95 (1996) 212

29. J. L. ARIAS, F. J. GARCIAS-SANZ, M. B. MAYOR, S. CHIUSSI, J. POU, B. LEON and M. PEREZ-AMOR, Biomaterials. 19 (1998) 883

30. F. GARCIA, J. L. ARIAS, B. MAYOR, J. POU, I. REHMAN, J. KNOWLES, S. BEST, B. LEON and M. PEREZ-AMOR, $J$. Biomed. Mat. Res. (Appl. Biomater.). 43 (1998) 69

31. C. M. ROOME and C. D. ADAM, Biomaterials. 16 (1995) 691

32. W. TONG, J. CHEN, X. LI, J. FENG, Y. CAO, Z. YANG and X. ZHANG, J. Mat. Sci. 31 (1996) 3739

33. J. D. LONG, S. XU, J. W. CAI, N. JIANG, J. H. LU, K. N. OSTRIKOV and C. H. DIONG, Mat. Sci. Eng. C. 20 (2002) 175

34. T. M. LEE, E. CHANG and C. Y. YANG, J. Mat. Sci. Mat. Med. 9 (1998) 439

35. P. M. KUMAR, S. BADRINARAYANAN and M. SASTRY, Thin Solid Films. 358 (2000) 122

36. A. R. BOYD, M. AKAY and B. J. MEENAN, Surf. Inter. Anal. 35 (2003) 188

37. K. VAN DIJK, J. VERHOEVEN, C. H. M. MAREE, F. H. P. M. HABRAKEN and J. A. JANSEN, Thin Solid Films. 304 (1997) 191

38. M. YOSHINARI, T. HAYAKAWA, J. G. C. WOLKE, K. NEMOTO and J. A. JANSEN, J. Biomed. Mat. Res. 37 (1997) 60

39. J. G. C. WOLKE, K. DE GROOT and J. A. JANSEN, J. Mat. Sci. 33 (1998) 3371

40. J.D PASTERIS, B. WOPENKA, J. J. FREEMAN, K. ROGERS, E. VALSAMI-JONES, J. A. M. VAN DER HOUWEN and M. J. SILVA, Biomaterials. 25 (2004) 229

41. L. J. JHA, J. D. SANTOS and J. C. KNOWLES, J. Biomed. Mat. Res. 31 (1996) 481

42. S-H. OH, R. R. FINONES, C. DARAIO, L-H. CHEN and S. JIN, Biomaterials. 26 (2005) 4938

43. X. F. XIAO, R. F. LIU and Y. Z. ZHENG, Surf. Coat. Tech. 200 (2006) 4406

44. B. KASEMO and J. GOLD, Adv. Dent. Res. 13 (1999) 8

45. P. J. LI, I KANGASNIEMI, K. DE GROOT and T. KOKUBO, $J$. Amer. Cer. Soc. 77 (1994) 1307

46. M. UCHIDA, H. M. KIM, T. KOKUBO, S. FUJIBASYASHI and T. NAKAMURA, J. Biomed. Mat. Res. 64 (2003) 164

47. J. WU, S. HAYAKAWA, K. TSURU and A. OSAKA, J. Amer. Cer. Soc. 87 (2004) 1635

48. P. A. RAMIRES, A. ROMITO, F. COSENTINO and E. MILELLA, Biomaterials. 21 (2001) 1467

49. H. KIM, H. -E. KIM, V. SALIH and J. C. KNOWLES, J Biomed Mater Res Part B Appl Biomater. 72B (2005) 1 